\title{
Evaluation of the cutting ability of two reciprocating instruments (WaveOne Gold e W-file)
}

Avaliação da capacidlade de corte de dois instrumentos reciprocantes após terceiro uso (WaveOne Gold e W-file)

Evaluación de la capacidad de corte de dos instrumentos alternativos después del tercer uso (WaveOne Gold y W-file)

Adolfo de Matos de Carvalho ORCID: https://orcid.org/0000-0002-4421-660X Faculdade de Ilhéus, Brazil E-mail: adolfodecarvalho@outlook.com

Marcely Reis da Silva ORCID: https://orcid.org/0000-0003-3807-4286 Faculdade de Ilhéus, Brazil E-mail: marcelyrs@outlook.com Matheus Almeida Rodrigues ORCID: https://orcid.org/0000-0001-9262-3704 Faculdade de Ilhéus, Brazil E-mail: mathsalmeidaaa@gmail.com

Edeilton Santana de Oliveira Júnior ORCID: https://orcid.org/0000-0001-6766-8855 Faculdade de Ilhéus, Brazil E-mail: edeiltonjunior@hotmail.com

Caio Cesar Souza

ORCID: https://orcid.org/0000-0002-6445-5157 ENDOBAHIA Cursos, Brazil

E-mail: caioitaobim@hotmail.com

Cesar Augusto Perini Rosas ORCID: https://orcid.org/0000-0002-2234-5531 Universidade Estadual do Norte do Paraná, Brazil E-mail: cesarperini66@hotmail.com

Ryhan Menezes Cardoso ORCID: https://orcid.org/0000-0003-3072-5347 Instituto Odontológico das Américas, Brazil E-mail:ryhann@hotmail.com

Ana Grasiela da Silva Limoeiro ORCID: https://orcid.org/0000-0003-4633-720X Faculdade de Ilhéus, Brazil E-mail: grasielalimoeiro@gmail.com

\begin{abstract}
Instrumentation is a fundamental step in endodontic treatment to promote proper cleaning and shaping of the canal. The objective of this study was to compare the cutting capacity of two reciprocal nickel-titanium systems in simulated canal blocks. Sixty acrylic blocks were used, divided into two groups of reciprocal files (WaveOne Gold - WOG and W-File - WF), each with 30 blocks and divided into 3 groups $(n=10)$ representing the first, second and third uses: WOG1, WOG2, WOG3, WF1, WF2, and WF3, respectively. Ink was injected into the simulated channels, which were covered with laminated paper to avoid affecting the instrumentation. For irrigation, $5 \mathrm{~mL}$ of saline was used at each instrument change. At the end of instrumentation, the blocks were photographed and analyzed in a computer program to compare the results before and after instrumentation. In the statistical analysis, the tests $\mathrm{S}$ Shapiro-Wilk, $\mathrm{T}$ for independent samples and Mann Whitney were performed. Under the experimental conditions in which this study was conducted, it is concluded that there were no significant differences in apical transport after the third application. However, the instruments of the W-File group had more conservative preparations with a better centralization capacity compared to the instruments of the WaveOne Gold group, which caused preparations with a larger diameter.
\end{abstract}

Keywords: Endodontics; Simulated canals; WaveOne Gold; W-File. 


\begin{abstract}
Resumo
A instrumentação é um passo fundamental no tratamento endodôntico para promover uma adequada limpeza e modelagem do conduto. O objetivo desse estudo foi comparar a capacidade de corte de dois sistemas reciprocante de níquel-titânio em blocos de canais simulados. Foram utilizados 60 blocos de acrílico, que foram separados em dois grupos de limas reciprocantes (WaveOne Gold - WOG e W-File - WF) com 30 blocos cada, e subdivididos em 3 grupos $(\mathrm{n}=10)$, representando o primeiro, segundo e terceiro uso: WOG1, WOG2, WOG3, WF1, WF2 e WF3. Foi injetada tinta nanquim nos canais simulados, os quais foram cobertos com papel laminado, para não haver influência na instrumentação. Para irrigação foram utilizados $5 \mathrm{~mL}$ de solução salina a cada troca de instrumento. Após o término das instrumentações, os blocos foram fotografados e analisados em um programa de computador para comparar o pré e pósinstrumentação. Na análise estatística foram realizados os testes S Shapiro-Wilk, T para amostras independentes e Mann Whitney. Nas condições experimentais que essa pesquisa foi conduzida, conclui-se que após o terceiro uso não houve diferenças significativa em relação ao transporte apical, porém, os instrumentos do grupo W-File obtiveram preparos mais conservadores, com uma melhor capacidade de centralização em comparação com os instrumentos do grupo WaveOne Gold, que ocasionaram preparos com um maior diâmetro.
\end{abstract}

Palavras-chave: Canais simulados; Endodontia; WaveOne Gold; W-File.

\title{
Resumen
}

La instrumentación es un paso fundamental en el tratamiento de endodoncia para promover la limpieza y el modelado adecuados del conducto. El objetivo de este estudio fue comparar la capacidad de corte de dos sistemas alternativos de níquel-titanio en bloques de canales simulados. Se utilizaron sesenta bloques acrílicos, que se separaron en dos grupos de limas recíprocas (WaveOne Gold - WOG y W-File - WF) con 30 bloques cada uno, y subdivididos en 3 grupos ( $\mathrm{n}=$ 10), representando el primero, segundo y tercero. uso: WOG1, WOG2, WOG3, WF1, WF2 y WF3. Se inyectó tinta tinta en los canales simulados, que se cubrieron con papel laminado, para no influir en la instrumentación. Para la irrigación, se utilizaron $5 \mathrm{ml}$ de solución salina en cada cambio de instrumento. Una vez finalizada la instrumentación, los bloques se fotografiaron y analizaron en un programa informático para comparar el pre y posinstrumentación. En el análisis estadístico se realizaron las pruebas S Shapiro-Wilk, T para muestras independientes y Mann Whitney. En las condiciones experimentales en las que se realizó esta investigación, se concluye que luego del tercer uso no hubo diferencias significativas en relación con el transporte apical, sin embargo, los instrumentos del grupo W-File tuvieron preparaciones más conservadoras, con una mejor capacidad de centralización. en comparación con los instrumentos del grupo WaveOne Gold, lo que provocó preparaciones de mayor diámetro.

Palabras clave: Canales simulados; Endodoncia; WaveOne Gold; W-file.

\section{Introduction}

One of the most important steps in endodontic treatment is mechanical-chemical preparation (PQM), in which we use rinsing substances for chemical cleaning and sharp instruments for mechanical cleaning. Through PQM, we achieve adequate cleaning of root canals, which requires harmony between irrigation and instrumentation to reduce the bacterial community. (Metzger et al., 2013).

In addition to cleaning, shaping the canal is also important, and files play an important role in this process. Over the past 30 years, files have undergone continuous evolution, from hand-held stainless steel instruments to innovative nickel-titanium (NiTi) files that are superior to stainless steel files. (Yoo \& Cho, 2012; Atmeh \& Watson, 2016). Reciprocal movements are somewhat more efficient compared to rotary instruments and offer some advantages, such as reducing cyclic fatigue, instrument torsion, and optimizing working time (Da Graça \& Paiva, 2020).

In this study, WaveOne Gold files (Dentsply Maillefer, Ballaigues, Switzerland) and W files (TDKaFile, Shenzhen, China) were selected to evaluate cutting efficiency after their third use in simulated canals in acrylic blocks. The WaveOne Gold file has a cutting edge made of $\mathrm{Ni}$-Ti and has been improved in manufacturing to increase elasticity. The W-File file, on the other hand, is also made of $\mathrm{Ni}-\mathrm{Ti}$ and has instruments with different tip sizes and tapers and a parallelogram cross-section similar to that of the WaveOne Gold (Calefi et al., 2019), (Metzger et al., 2013).

In clinical practice, we always try to optimize the time in service without losing efficiency. For this reason, we are looking for an endodontic system that is faster and requires fewer files. Therefore, the techniques should shorten the working time and reduce cross-contamination between patient and practitioner, a common problem when using multiple files (Vallabhaneni et al., 2012). 
Therefore, this study will analyze which of these files provide better cutting, cleaning, and modeling after their third use in the simulated canals.

\section{Methodology}

Sixty acrylic blocks (IM Brazil, São Paulo Brazil) were divided into 2 groups of reciprocating files: WaveOne Gold 25.07 (WOG-Dentsply Maillefer, Ballaigues, Switzerland) and W-File 25.07 (WF-TDK, China). The groups were sub-divided into 3 subgroups $(\mathrm{n}=10)$ WOG1, WOG2, WOG3, WF1, WF2 and WF3, representing the cycle with which the instruments were used.

The acrylic blocks were filled with black nankin paint (Acrilex, China) and photographs were taken to record the original shapes of the channels. In order not to influence the instrumentation, the blocks were wrapped with laminated paper, and then placed in a lathe (TORNIN, Belo Horizonte, Brazil) with the curvature facing left.

During instrumentation, all simulated root canals were prepared by an experienced operator as indicated by the manufacturers. All canals were prepared with iRoot Pro endodontic engine (Bassi/ Easy Equipamentos Odontológico), with the following angles: $170^{\circ}-50^{\circ}$. Before root canal preparation, the WF files were sterilized. The working length (CT) was determined as $17 \mathrm{~mm}$ (total length of the simulated canal). Each file was used with 3 pecking movements and then removed from the canal and cleaned with gauze. After three movements, the instrument was removed, and the canals irrigated with $5 \mathrm{~mL}$ of $0.9 \%$ saline solution in a hypodermic syringe and Endo-Eze needle (Ultradent Products, Utah, United States). After instrumentation of each canal, all files were autoclaved at $126^{\circ} \mathrm{C}, 30 \mathrm{psi}$ for 26 minutes. The instrumentation and autoclaving process was repeated for subgroups WOG2 and WF2, followed by groups WOG3 and WF3. The acrylic blocks were placed in the pre-established fixed initial position to take post-instrumentation photographs of each instrumented block.

The corresponding pre- and post-instrumentation images were overlaid with Adobe Photoshop CS6 (Adobe Systems, San Jose, USA). For the evaluation of the blocks, five different points were established: canal orifice (a), in the middle of the canal (b), the beginning of the curve (c), the apex of the curve (d) and the end point (e). The 5 points served as a reference to compare pre-instrumentation and post-instrumentation images (Keskin, et al. 2018) (Figure 1). 
Figure 1. Pre and post instrumentation image overlay with measurement points (a) canal orifice, (b) midway between the canal orifice and the beginning of the curve, (c) the beginning of the curve, (d) the apex of the curve, (e) the end point of the simulated canal.

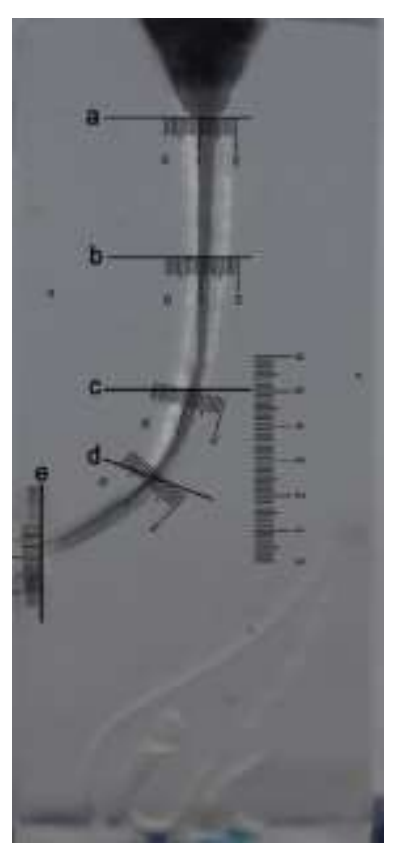

Source: Own authorship.

Images before and after instrumentation were overlaid with Adobe Photoshop to assess canal centering and transport.

To measure the centering ability of the canal, the transport distance was measured at each point by plotting the measurements from the center of the pre-instrumented canal to the post-instrumented points, where X1 is the maximum extent of instrument movement toward the inside of the curvature, $\mathrm{X} 2$ is the movement of the instrument in the opposite direction, and $\mathrm{Y}$ is the final diameter of the canal preparation. After collecting these data, the formula Total was applied: X1-X2/Y (LIM et al 2013). (Figure 2)

Figure 2. X1 represents the maximum amount of movement from the canal to the inside of the curve and X2 represents movement in the opposite direction. $\mathrm{Y}$ is the diameter of the final canal preparation.

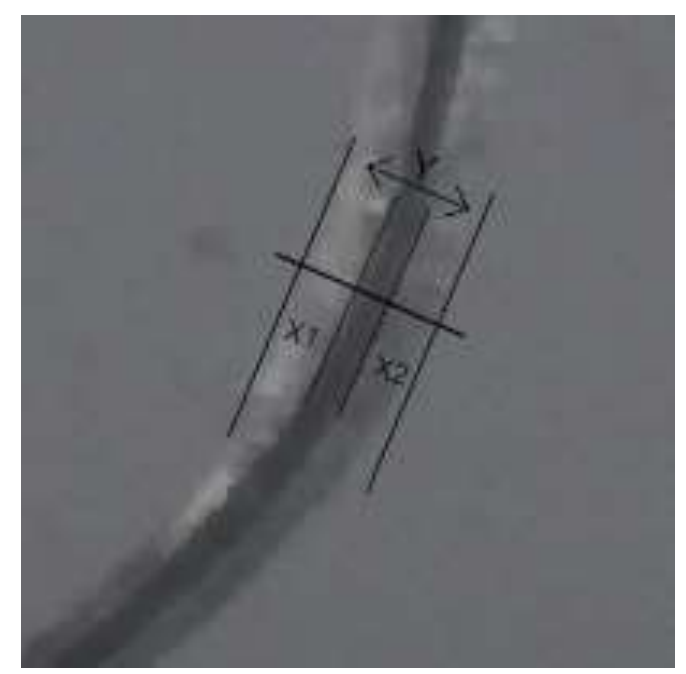

Source: Own authorship. 
In the statistical analysis, the S Shapiro-Wilk test was performed, the purpose of which is to check whether the data had a normally distributed distribution $(\mathrm{p}>0.05)$ or not $(\mathrm{p}<0.05)$. If the data were normally distributed, the $\mathrm{T}$-test for independent samples was used, if they were not normally distributed, the Mann Whitney test was used.

\section{Results}

During the development of the research, after the second use of the files, one instrument in the WOG group was broken and one instrument in the WF group was displaced. Table 1 shows the total width of the conduit after the first, second and third use with WF and WOG files at the end of instrumentation.

Table 1. total width $(\mathrm{mm})$ of canal at 5 different measuring points after canal preparation with 2 reciprocal instruments.

\begin{tabular}{|c|c|c|c|c|c|c|c|c|c|}
\hline \multirow[b]{2}{*}{ Mesurement point } & \multicolumn{3}{|c|}{$1^{\circ}$ Uso } & \multicolumn{3}{|c|}{$2^{\circ}$ Uso } & \multicolumn{3}{|c|}{$3^{\circ}$ Uso } \\
\hline & W-file & $\begin{array}{c}\text { WaveOne } \\
\text { Gold }\end{array}$ & $\begin{array}{l}\mathrm{p} \text { va- } \\
\text { lue }\end{array}$ & W-file & $\begin{array}{c}\text { WaveOne } \\
\text { Gold }\end{array}$ & $\begin{array}{l}\text { p va- } \\
\text { lue }\end{array}$ & W-file & $\begin{array}{c}\text { WaveOne } \\
\text { Gold }\end{array}$ & $\begin{array}{c}\mathrm{p} \text { va- } \\
\text { lue }\end{array}$ \\
\hline (a) Canal oriffice & $1,14 \pm 0,16^{\mathrm{a}}$ & $1,43 \pm 0,11^{\mathrm{b}}$ & 0 & $1,2 \pm 0,16^{\mathrm{a}}$ & $1,31 \pm 0,15^{\mathrm{a}}$ & 0,137 & $1,3 \pm 0,12^{\mathrm{a}}$ & $1,43 \pm 0,12^{\mathrm{b}}$ & 0,022 \\
\hline $\begin{array}{l}\text { (b) Halfway between the } \\
\text { orifice and the beginning of } \\
\text { the curve }\end{array}$ & $0,96 \pm 0,14^{\mathrm{a}}$ & $1,23 \pm 0,15^{b}$ & 0,001 & $1,06 \pm 0,22^{\mathrm{a}}$ & $1,12 \pm 0,21^{\mathrm{a}}$ & 0,547 & $1,03 \pm 0,15^{\mathrm{a}}$ & $1,15 \pm 0,10^{\mathrm{b}}$ & 0,017 \\
\hline (c) Beginning of the curve & $0,86 \pm 0,16^{\mathrm{a}}$ & $1,07 \pm 0,19^{b}$ & 0,008 & $0,81 \pm 0,18^{a}$ & $0,71 \pm 0,18^{a}$ & 0,228 & $0,81 \pm 0,15^{a}$ & $0,91 \pm 0,12^{\mathrm{a}}$ & 0,121 \\
\hline (d) Apex of the curve & $0,62 \pm 0,10^{\mathrm{a}}$ & $0,88 \pm 0,23^{b}$ & 0,004 & $0,76 \pm 0,15^{\mathrm{a}}$ & $0,71 \pm 0,13^{\mathrm{a}}$ & 0,435 & $0,6 \pm 0,11^{\mathrm{a}}$ & $0,71 \pm 0,09^{b}$ & 0,021 \\
\hline (e) End-point of the canal & $0,5 \pm 0,11^{\mathrm{a}}$ & $0,76 \pm 0,24^{b}$ & 0,004 & $0,74 \pm 0,17^{\mathrm{a}}$ & $0,72 \pm 0,20^{\mathrm{a}}$ & 0,812 & $0,48 \pm 0,08^{a}$ & $0,56 \pm 0,13^{\mathrm{a}}$ & 0,136 \\
\hline
\end{tabular}

Values are presented as means \pm standard deviations. Letters equal in the horizontal direction indicate that there were no significant differences between groups. Different letters indicate statistical differences between groups. Source: own authorship.

At the end of the first use, there was a significant difference in all measurement points. The WF1 group received a more conservative preparation at all five points of the canal and the WOG1 group received a preparation with greater wear.

After the second use there were no significant differences between the files. The WOG2 group was more conservative at the beginning of the curve (c), at the apex of the curve (d), and at the end point of the canal (e), while the WF2 group removed less resin in the canal opening (a) and in the middle of the canal (b).

After the third use, there were significant differences in the orifice of the canal (a), in the middle of the canal (b), and at the apex of the curve (d). The WF3 group again achieved a more conservative canal preparation in all five points compared to the WOG3 group, which applied greater wear to the canal. Table 2 shows the average amount of resin removed into the acrylic blocks after the first, second, and third applications. 
Table 2. measurements of the inner and outer width $(\mathrm{mm})$ of the canals at 5 different measuring points after canal preparation with 2 reciprocal instruments.
(a) Canal oriffice
(b) Halfway between the orifice and the beginning
(c) Beginning of the curve
(d) Apex of the curve
(e) End-point of the point of the curve

\begin{tabular}{|c|c|c|c|c|c|c|c|c|c|c|}
\hline & Inner & Outer & Inner & Outer & Inner & Outer & Inner & Outer & Inner & Outer \\
\hline WF1 & $0,26 \pm 0,05^{a}$ & $0,39 \pm 0,1^{\mathrm{a}}$ & $0,23 \pm 0,05^{\mathrm{a}}$ & $0,33 \pm 0,18^{a}$ & $0,35 \pm 0,08^{a}$ & $0,14 \pm 0,10^{\mathrm{a}}$ & $0,21 \pm 0,09^{a}$ & $0,1 \pm 0,09^{\mathrm{a}}$ & $0,15 \pm 0,05^{\mathrm{a}}$ & $0,13 \pm 0.09^{a}$ \\
\hline $\begin{array}{c}\text { WOG } \\
1 \\
\end{array}$ & $0,30 \pm 0,17^{b}$ & $0,65 \pm 0,1^{\mathrm{a}}$ & $0,30 \pm 0,11^{\mathrm{b}}$ & $0,56 \pm 0,21^{\mathrm{a}}$ & $0,51 \pm 0,15^{\mathrm{a}}$ & $0,28 \pm 0,19^{a}$ & $0,36 \pm 0,18^{a}$ & $0,26 \pm 0,15^{\mathrm{a}}$ & $0,19 \pm 0,07^{b}$ & $0,32 \pm 0,18^{a}$ \\
\hline WF2 & $0,22 \pm 0,21^{\mathrm{a}}$ & $0,4 \pm 0,16^{\mathrm{a}}$ & $0,19 \pm 0,20^{\mathrm{a}}$ & $0,38 \pm 0,20^{\mathrm{a}}$ & $0,19 \pm 0,19^{a}$ & $0,26 \pm 0,20^{\mathrm{a}}$ & $0,14 \pm 0,16^{\mathrm{a}}$ & $0,34 \pm 0,08^{\mathrm{a}}$ & $0,33 \pm 0,09^{\mathrm{a}}$ & $0,33 \pm 0,11^{\mathrm{a}}$ \\
\hline $\begin{array}{c}\text { WOG } \\
2 \\
\end{array}$ & $0,30 \pm 0,20^{b}$ & $0,35 \pm 0,14^{b}$ & $0,33 \pm 0,18^{\mathrm{b}}$ & $0,44 \pm 0,18^{b}$ & $0,31 \pm 0,19^{b}$ & $0,03 \pm 0,07^{\mathrm{a}}$ & $0,17 \pm 0,13^{b}$ & $0,31 \pm 0,12^{\mathrm{b}}$ & $0,37 \pm 0,09^{b}$ & $0,28 \pm 0,13^{\mathrm{b}}$ \\
\hline WF3 & $0,35 \pm 0,12^{\mathrm{a}}$ & $0,44 \pm 0,07^{\mathrm{a}}$ & $0,27 \pm 0,09^{\mathrm{a}}$ & $0,34 \pm 0,11^{\mathrm{a}}$ & $0,31 \pm 0,07^{\mathrm{a}}$ & $0,16 \pm 0,13^{\mathrm{a}}$ & $0,16 \pm 0,08^{\mathrm{a}}$ & $0,12 \pm 0,09^{\mathrm{a}}$ & $0,09 \pm 0,13^{\mathrm{a}}$ & $0,11 \pm 0,09^{\mathrm{a}}$ \\
\hline $\begin{array}{c}\text { WOG } \\
3\end{array}$ & $0,36 \pm 0,14^{\mathrm{b}}$ & $0,5 \pm 0,09^{b}$ & $0,30 \pm 0,11^{\mathrm{b}}$ & $0,39 \pm 0,03^{b}$ & $0,37 \pm 0,13^{\mathrm{b}}$ & $0,17 \pm 0,11^{\mathrm{b}}$ & $0,20 \pm 0,07^{\mathrm{b}}$ & $0,19 \pm 0,07^{b}$ & $0,13 \pm 0,08^{b}$ & $0,17 \pm 0,07^{b}$ \\
\hline
\end{tabular}

Values are presented as means \pm standard deviations. Different superscript letters indicate a statistically significant difference between groups $(\mathrm{p}<0.05)$. Source: Own authorship.

In the first use, there were significant differences between the WOG1 and WF1 files on the inside at the beginning of the curve (c), at the apex of the curve (d), on the outside of the curve at the canal opening (a), in the middle of the canal (b), at the beginning of the curve (c), at the apex of the canal (d), and at the end point of the canal (e). At all points examined, significantly more resin was removed from the outside of the curve with the WOG1 instrument. Analysis of the second application showed that there were significant differences on the outside at the beginning of the curve (c). The files of the WOG2 group removed more resin on the inside of the curve at all measurement points, and on the outside of the curve, the WF2 group showed higher wear at all points of the canal. After the third application, there were no significant differences between the files. The WOG3 group removed more resin from the inside and outside of the curve at the five measurement points compared to the WF3 files. Table 3 shows the mean transport values regardless of the direction of the 5 measurement points.

Table 3. Canal transport distance $(\mathrm{mm})$ at 5 different measuring points after canal preparation with 2 reciprocal instruments.

\begin{tabular}{|c|c|c|c|c|c|c|c|c|c|}
\hline \multirow[b]{2}{*}{ Mesurement point } & \multicolumn{3}{|c|}{$1^{\circ}$ use } & \multicolumn{3}{|c|}{$2^{\circ}$ use } & \multicolumn{3}{|c|}{$3^{\circ}$ use } \\
\hline & W-file & $\begin{array}{l}\text { WaveOne } \\
\text { Gold }\end{array}$ & $\begin{array}{c}\mathrm{p} \text { va- } \\
\text { lue }\end{array}$ & W-file & $\begin{array}{l}\text { WaveOne } \\
\text { Gold }\end{array}$ & $\begin{array}{c}\mathrm{p} \text { va- } \\
\text { lue }\end{array}$ & $\mathrm{W}$-file & $\begin{array}{l}\text { WaveOne } \\
\text { Gold }\end{array}$ & $\begin{array}{l}\text { p va- } \\
\text { lue }\end{array}$ \\
\hline (a) Canal oriffice & $-0,10 \pm 0,10^{\mathrm{a}}$ & $-0,24 \pm 0,24^{\mathrm{b}}$ & 0,049 & $-0,15 \pm 0,23^{\mathrm{a}}$ & $-0,05 \pm 0,22^{\mathrm{a}}$ & 0,322 & $-0,07 \pm 0,12^{\mathrm{a}}$ & $-0,10 \pm 0,14^{\mathrm{a}}$ & 0,845 \\
\hline $\begin{array}{l}\text { (c) Beginning of the } \\
\text { curve }\end{array}$ & $0,26 \pm 0,17^{a}$ & $0,22 \pm 0,26^{\mathrm{a}}$ & 0,655 & $-0,11 \pm 0,32^{\mathrm{a}}$ & $0,35 \pm 0,22^{\mathrm{b}}$ & 0,002 & $0,21 \pm 0,25^{\mathrm{a}}$ & $0,20 \pm 0,21^{\mathrm{a}}$ & 1,000 \\
\hline $\begin{array}{l}\text { (e) End-point of the ca- } \\
\text { nal }\end{array}$ & $0,03 \pm 0,33^{\mathrm{a}}$ & $-0,14 \pm 0,23^{a}$ & 0,213 & $-0,05 \pm 0,17^{\mathrm{a}}$ & $0,12 \pm 0,23^{\mathrm{a}}$ & 0,087 & $-0,05 \pm 0,13^{\mathrm{a}}$ & $-0,07 \pm 0,15^{\mathrm{a}}$ & 0,740 \\
\hline
\end{tabular}

Values are presented as means \pm standard deviations. Different superscript letters indicate a statistically significant difference between groups ( $\mathrm{p}$ < 0.05). Source: Own authorship. 
After analysis of the first use, there was a significant difference between the files only in the canal orifice (a). At the second use, there were significant differences at the beginning of the curve (c). At the end of the third use, there were no significant differences, i.e., both files transported/removed the same amount of resin from the canal.

\section{Discussion}

The aim of this study was to compare two reciprocal systems depending on their cleaning and shaping quality in simulated canals in acrylic blocks after their third use.

Simulated canals in acrylic blocks were used to evaluate the shaping ability of the two experimental files. (Silva et al, 2021). Although extracted human teeth provide conditions very similar to clinical conditions, they exhibit a wide range of root canal morphology. (Schaefer et al., 2004; Huelsmann et al., 2003).

Studies in acrylic blocks allow standardization of the diameter, angle of curvature, and length of the original shape and comparison of the configuration after using different instruments (Schaefer et al., 1995; Piazza et al., 2021). The lower surface stiffness compared to dentin and the probable softening of the acrylic resin due to friction during canal preparation are the disadvantages of this technique (Lim et al., 2013). Although manufacturers recommend the single use of files, this does not correspond to the reality of everyday clinical practice (Yao et al., 2006). Based on this idea, files were sterilized after each use to simulate clinical conditions.

Although Pelepenko et al. 2020 concluded that both WF and WOG were safe when used according to the manufacturer's recommendations, one WOG broke after the second use. In addition, root canal deviation occurred with the WF instrument, confirming studies showing that the more frequently the instrument is used, the more likely it is to fracture (Amaral et al., 2004; Menezes et al., 2017). RC and WO instruments showed good fracture resistance after autoclave sterilization and reuse. (ManigliaFerreira et al. 2017).

According to the literature, the shaping and cutting ability of the WOG instruments have not yet been compared with that of the W-File, so further studies should be conducted to discuss the results obtained in this study. The files of the WOG group offered a less conservative preparation after the three uses, resulting in preparations with a larger diameter compared to the WF file group. A similar study using acrylic blocks compared the shaping of different rotary and reciprocal systems, including Reciproc, WaveOne, HyflexCM, F360, and OneShape, and concluded that WaveOne had greater canal deformation among the reciprocal systems (Burklein et al., 2014Reciproc and WaveOne instruments maintained the original canal curvature in curved canals better than ProTaper and Profile, which tend to transport in the apical part of the canal toward the outer canal wall of the curvature. (Yoo \& Cho, 2012).

Keskin et al. 2018 compared the shaping ability of the Reciproc Blue R25 with the WOG instrument and concluded that WOG produced a more conservative enlargement with less apical transport. In this study, the WF group achieved better centering ability than the WOG group when the instrument was used in the simulated canal at the end of the three uses. Reciproc (VDW, Munich, Germany) showed less deviation, greater centration of the preparation, and better canal formatting than WaveOne (Dentsply Maillefer, Ballaigues, Switzerland) (Silva et al., 2015). Nickel-titanium files have revolutionized the practice of endodontics in several ways due to their superelasticity, although studies show that biomechanical preparation is not effective in removing organic and inorganic debris in root canals. (Williamson et al., 2009; Taha et al., 2010).

\section{Conclusion}

Under the experimental conditions in which this study was conducted, it was concluded that there were no significant differences in apical transport after the third uses. However, the instruments of the W-File group had more conservative preparations with a better centralization capacity compared to the instruments of the WaveOne Gold group, which caused preparations 
with a larger diameter.

\section{References}

Amaral, G., Lopes, H. P., Bombana, A. C., \& Elias, C. (2004). Avaliação da capacidade de corte de limas tipo K de aço inoxidável e de Níquel-Titânio. JBE, J. Bras. Endod, 223-230.

Atmeh, A. R., \& Watson, T. F. (2016). Root dentine and endodontic instrumentation: cutting edge microscopic imaging. Interface focus, 6(3), 20150113.

Bürklein, S., Hinschitza, K., Dammaschke, T., \& Schäfer, E. (2012). Shaping ability and cleaning effectiveness of two single-file systems in severely curved root canals of extracted teeth: Reciproc and WaveOne versus Mtwo and ProTaper. International endodontic journal, 45(5), 449-461.

Bürklein, S., Poschmann, T., \& Schäfer, E. (2014). Shaping ability of different nickel-titanium systems in simulated S-shaped canals with and without glide path. Journal of endodontics, 40(8), 1231-1234.

Calefi, P. H. S., Osaki, R. B., Evedove, N. F. D., Cruz, V. M., Andrade, F. B., \& Alcalde, M. P. (2020). Cyclic and torcional fatigue resistance of W File and X1 Blue file reciprocating instruments. Dental Press Endod.May-Aug;10(2):60-6.

Da Graça, E. V., \& Paiva, S. S. M. (2020). Limas Reciprocantes No Canal Radicular. Cadernos De Odontologia do UNIFESO, 1(2).

De Menezes, S. E. A. C., Batista, S. M., Lira, J. O. P., \& de Melo Monteiro, G. Q. (2017). Cyclic fatigue resistance of WaveOne Gold, ProDesign R and ProDesign Logic files in curved canals in vitro. Iranian endodontic journal, 12(4), 468.

Hülsmann, M., Gressmann, G., \& Schäfers, F. (2003). A comparative study of root canal preparation using FlexMaster and HERO 642 rotary Ni-Ti instruments. International Endodontic Journal, 36(5), 358-366.

Keskin, C., Demiral, M., \& Sariyllmaz, E. (2018). Comparison of the shaping ability of novel thermally treated reciprocating instruments. Restorative dentistry \& endodontics, $43(2)$.

Lim, Y. J., Park, S. J., Kim, H. C., \& Min, K. S. (2013). Comparison of the centering ability of Wave- One and Reciproc nickel-titanium instruments in simulated curved canals. Restorative dentistry \& endodontics, 38(1), 21-25.

Maniglia-Ferreira, C., de Almeida Gomes, F., Ximenes, T., Neto, M. A. T., Arruda, T. E., Ribamar, G. G., \& Herculano, L. F. G. (2017). Influence of reuse and cervical preflaring on the fracture strength of reciprocating instruments. European journal of dentistry, 11(01), 041-047.

Metzger, Z., Solomonov, M., \& Kfir, A. (2013). The role of mechanical instrumentation in the cleaning of root canals. Endodontic Topics, 29(1), 87-109.

Pelepenko, L. E., Zanin, E., Langaro, M. C., Machado, R. L., Fornari, V. J., \& Hartmann, M. S. M. (2020). Resistência à fratura de instrumentos reciprocantes WaveOne-Gold e W-File. Full Dent. Sci. 11(44).

Piazza, G. C., et al. Avaliação do número de canais modelados com limas Prodesing M até sua fratura, simulado em blocos de resina acrílica. Revista Orbis Science, 46-56, 2021.

Schäfer, E., \& Vlassis, M. (2004). Comparative investigation of two rotary nickel-titanium instruments: ProTaper versus RaCe. Part 1 . Shaping ability in simulated curved canals. International endodontic journal, 37(4), 229-238.

Schäfer, E., Tepel, J., \& Hoppe, W. (1995). Properties of endodontic hand instruments used in rotary motion Part 2. instrumentation of curved canals. Journal of Endodontics, 21(10), 493-497.

Silva, E. J. N. L., Vieira, V. C. G., Tameirão, M. D. N., Belladonna, F. G., Neves, A. D. A., Souza, E. M., \& De-Deus, G. (2016). Quantitative transportation assessment in curved canals prepared with an off-centered rectangular design system. Brazilian oral research, 30.

Silva, M.R., Carvalho, A. M., Rodrigues, M. A., Bezerra, E. S., Souza, C. C., Rosas, C. A., Cardoso, R. M., Limoeiro, A. G. (2021). Estudo in vitro da limpeza de canais simulados (Wave One Gold X W-file). Research, Society and Development, 10(13), 1-8.

Taha, N. A., Ozawa, T., \& Messer, H. H. (2010). Comparison of three techniques for preparing oval-shaped root canals. Journal of endodontics, $36(3), 532-535$.

Vallabhaneni, S., More, G. R., \& Gogineni, R. (2012). Single file endodontics. Indian Journal of Dental Advancements, 4(2), 822-827.

Williamson, A. E., Sandor, A. J., \& Justman, B. C. (2009). A comparison of three nickel titanium rotary systems, EndoSequence, ProTaper universal, and profile GT, for canal-cleaning ability. Journal of endodontics, 35(1), 107-109.

Yao, J. H., Schwartz, S. A., \& Beeson, T. J. (2006). Cyclic fatigue of three types of rotary nickel-titanium files in a dynamic model. Journal of endodontics, 32(1), $55-57$.

Yoo, Y. S., \& Cho, Y. B. (2012). A comparison of the shaping ability of reciprocating NiTi instruments in simulated curved canals. Restorative Dentistry \& Endodontics, 37(4), 220-227. 